ANNALS, AAPSS, 537, January 1995

\title{
Ethics and the Public Administrator
}

\author{
By STEVEN COHEN and WILLIAM B. EIMICKE
}

\begin{abstract}
This article provides an overview and analysis of the practical problems of developing and implementing a code of ethics for public administrators. The article addresses three key issues: (1) What are public ethics and where do they come from? (2) What are the central ethical issues facing public administrators? and (3) Are there practical tools and guidelines to assist public servants to be both ethical and effective public managers? The article concludes with a plea for consideration of ethical issues, and it presents five general ethical principles for public administrators.
\end{abstract}

Steven Cohen is the associate dean of the School of International and Public Affairs at Columbia University and director of its Graduate Program in Public Policy and Administration. Cohen has served as policy analyst and consultant with the U.S. Environmental Protection Agency. He is the author of The Effective Public Manager.

William B. Eimicke is the director of the Public Management Training Center and the Program in Politics and Public Policy at Columbia University's School of International and Public Affairs. He recently served as consultant to Vice President Gore's National Performance Review and is a member of New York Mayor Guiliani's Business Advisory Group. 
$\mathrm{T}$ HE ethical conduct of our elected and appointed public officials has become a major subject of media attention in recent years. At the national level, the Iran-contra scandal; the unauthorized and undetected diversion of federal housing dollars and the politicization of funding decisions at the U.S. Department of Housing and Urban Development; the allegations of improper lobbying by U.S. senators-the Keating Five-for a failing savings and loan; recent questions regarding President Clinton's personal conduct while governor of Arkansas; as well as his and Mrs. Clinton's involvement in the Whitewater real estate deal-all these have attracted substantial and sustained press coverage and formal investigations.

During the eight years of the Reagan administration, over 150 toplevel appointed officials resigned as a result of ethical violations.

At the state and local level, ethical failings have been equally prevalent and well publicized. A major corruption scandal in New York City in the late 1980s resulted in the suicide of the Queens borough president and probably caused then Mayor Koch to lose his 1989 reelection bid. In 1992, 5000 citizens under the banner of Right Now rallied against corruption in Rhode Island's state legislature and forced through the enactment of major ethics reform laws. In Kentucky, the BOPTROT federal sting operation resulted in the criminal conviction of the head of that state's legislature, the resignation of others, and the passage of ethics legislation. Today, 36 states have ethics codes and commissions.
The 1990s may be, as Professor $\mathrm{H}$. George Frederickson has predicted, and Governing Magazine echoed, "the beginning of an era of ethics." Frederickson makes a strong case for his view. He argues that there is a perceived dramatic increase in government corruption. He continues that the issue is generally framed as good versus bad, so the stories are easy to comprehend and thereby have strong carrying capacity in the media. Finally, Frederickson maintains that continuing interest and a near flood of cases are ensured by the broad range of federal, state, and local ethics laws enacted in recent years. ${ }^{2}$

While we agree that ethical issues are likely to appear frequently in the news and in the courts for some time to come, we are concerned that the subject is generally not very well defined. As a result, the millions of public administrators who run the essential public services that we depend on daily are stressed, and they are often reduced to inaction for fear of violating some ethical standard that they only vaguely understand. These officials have no practical guide to determine the right decision in specific cases. Their problem is the central concern of this analysis.

Several key issues must be addressed: What are public ethics and where do they come from; what are the central ethical issues facing public administrators; and are there practical tools and guidelines to assist public servants to be active and ethical at the same time?

1. H. George Frederickson, ed., Ethics and Public Administration (Armonk, NY: M. E. Sharpe, 1993), p. 5.

2. Ibid. 
WHAT ARE PUBLIC ETHICS AND WHERE DO THEY COME FROM?

The discussion of public ethics and where they come from goes to the very heart of the American philosophy of government, beginning with the writings of John Locke. By most accounts, the framers of the U.S. Constitution and Bill of Rights were strongly influenced by Locke's Second Treatise of Government. In it, Locke argues that government is created by the people and remains accountable to them. Government has the political power to make and enforce laws, but only for the public good. ${ }^{3}$

In his $\mathbf{1 7 7 6}$ call to arms, Common Sense, Thomas Paine defined the objective of government to be the greatest sum of individual happiness at the least national expense, a distinctly utilitarian philosophy. ${ }^{4}$ In Tocqueville's view, we Americans valued sovereignty of the people, democracy, and equality as our public goals and the primary responsibilities of our government. ${ }^{5}$

Beyond the underlying philosophy, our Constitution and Bill of Rights are relatively specific about the purposes and responsibilities of our government. But how can we translate those broad statements into a contemporary, practical guide for the behavior of those in the thousands of administrative jobs throughout our three levels of government?

3. John Locke, Second Treatise of Government (New York: Bobbs-Merrill, 1952).

4. Thomas Paine, Common Sense and the Crisis (New York: Doubleday, 1960); John Stuart Mill, On Liberty (New York: Bobbs-Merrill, 1956).

5. Alexis de Tocqueville, Democracy in America (New York: New American Library, 1956).
In the late nineteenth and early twentieth century, the responsibilities and size of the administrative arm of government grew rapidly, and political theorists began to focus on how those in this nonelective branch could most responsibly discharge their duties. Woodrow Wilson, Luthur Gulick, Frederick Taylor and his scientific management followers, and the municipal reform movement leaders of the 1920s and 1930s all agreed that public administrators should be guided by the principles of efficiency, efficacy, and expertise in the neutral execution of their duties, what Pugh calls the "bureaucratic ethos." The practical value of this approach was effectively demolished with the rise of Nazi Germany and the subsequent Nuremberg trials. The premise that the responsibility of public administrators was to effectively carry out, but not question or evaluate, the dictates of their superiors and elected officials was clearly not sufficient.

Over the past four decades, many have attempted to define the proper role of the public administrator more completely. The venerable public servant and writer Elmer Staats has observed that " public service is a concept, an attitude, a sense of duty-yes, even a sense for public morality." "7 But what is that public morality, those public ethics? As public administrators seek to hone their

6. Darrell Pugh, "Origins of Ethical Frameworks in Public Administration," in Ethical Frontiers in Public Management, ed. James S. Bowman (San Francisco: JosseyBass, 1991), pp. 9-32.

7. In James L. Perry, "Public Service Motivation: Construct, Content and Reliability" (Paper delivered at the National Conference of 
moral skills, where can they look for guidance? Many would agree with the noted public ethics scholar Kathryn Denhardt that "ethics in public administration suffers from the absence of a theoretical framework."

In recent years, a number of public administration thinkers have tried to provide that missing structure. In his excellent Ethics for Bureaucrats, Rohr maintains that we need to move from avoiding scandals to developing virtues for those who govern. But given the wide range of policy issues facing public servants and the degree of discretion required, specific training is impossible. He therefore proposes a more general, middle-ofthe-road set of guidelines comprising the Constitution itself and the subsequent Supreme Court decisions that interpret and apply the Constitution. ${ }^{9}$

Four years later, Terry Cooper rejected Rohr's framework for failing to provide a process for ethical decision making. Cooper argues that the organizational context provides the bounds to ethical decision making and that if public administrators know and make only those decisions that it is legitimate for them to make, if the process provides representation and participation, and if the decision makers understand the organization's goals, then their decisions are bounded and they can be held accountable. Cooper may be cor-

the American Society for Public Administration, Washington, DC, 19 July 1993).

8. Kathryn G. Denhardt, The Ethics of Public Service: Resolving Moral Dilemmas in Public Organizations (Westport, CT: Greenwood Press, 1988), p. 1.

9. Ibid., pp. 18-19. rect, but there is not much in his framework to provide everyday guidance to the practitioner. ${ }^{10}$

More recently, Carol Lewis, sponsored by the American Society for Public Administration, sought to address this vexing problem of defining and applying public ethics. Lewis suggests that public ethics is different from personal ethics in terms of values and guiding principles. To Lewis, ethics is thinking systematically about morals and conduct and making judgments about right and wrong. In the public service, ethics must go beyond thinking to performance and action; hence public ethics comprises action-based judgments of right and wrong. To guide the public administrator in making such judgments, Lewis suggests using the concepts of responsibility and obligation from several perspectives, including a personal view, the perspective of humanity in general, a professional lens, the agency's goals and values, and the jurisdiction in which the decision is made. ${ }^{11}$

While Lewis also helps to build the theoretical framework for a science of public ethics, most practitioners would still be searching for more specific instructions on how to make the proper ethical decisions day to day. Perhaps a closer look at the issues included in public ethics codes and evaluated by public ethics commissions can bring us closer to an operational understanding of how ethical decisions can be made.

10. Ibid., p. 19.

11. Carol Lewis, The Ethics Challenge in Public Service (San Francisco: Jossey-Bass, 1990), p. 23. 


\section{CURRENT ISSUES IN PUBLIC ETHICS}

In the late $1980 \mathrm{~s}$, the massive Parking Violations Bureau scam in New York City, coupled with politicization of the mayor's appointment power through a City Hall talent clearinghouse, forced the governor and the state legislature to confront the matter of ethics in government directly and comprehensively. Their political lives were at stake. After much wrangling, they came up with a three-step approach-an investigative commission, an ethics law, and an ethics commission to enforce that law on an ongoing basis. The work of the commission and its final report helped shape the issues and the remedies incorporated into the law.

Known as the Public Officers Law, the New York State ethics law fills a 41-page booklet. Among the issues covered are restrictions on outside compensation; conflict-ofinterest provisions; prohibitions on gifts over $\$ 75$; limits on participation in political parties; substantial financial-disclosure provisions; a two-year revolving-door policy and restrictions on the appearance of former government officials before agencies for which they previously worked; prohibitions against legislators taking bribes; and empowerment of the Ethics Commission to impose fines. It is interesting to note that the provisions of the law are much less restrictive for legislators and legislative employees, and enforcement of violations by the legislative branch is left to the legislators themselves. The com- mission has no jurisdiction over their activities. ${ }^{12}$

As previously mentioned, laws similar to the New York State statute have been passed in 36 states and at the federal level. They certainly are helpful to the public employees because at least they know what is against the law and what will happen to them if they are caught violating the law. But we would argue that the fundamental problem for public employees does not lie in following the law. For the vast majority of them, following the law is what they do for a living; it is second nature. What is difficult for them is determining what to do in complex situations where there is no clear legal guidance. As Rohr comments, an issue such as appearance of impropriety "does not yield to the definitional exigencies of law and administrative regulation."

What is the responsibility of the public employee to broader issues of human rights, such as the fundamental freedoms supposedly guaranteed to all Americans by the Bill of Rights? No matter how small an impact it might have, what action should public employees take when a law or regulation restricts them from helping someone in poverty or compels them to make public information that they know will endanger the life of someone in the armed services or an undercover police officer? And what if they feel the activities of the public agency they work for are un-

12. State of New York, Ethics Commission, Public Officers Law (Albany: New York State, 1989).

13. In Frederickson, ed., Ethics and Public Administration, p. xii. 
ethical or even illegal? When and how do they decide to become a whistleblower?

The common method to attempt to deal with this somewhat gray area of proper public behavior is the promulgation of a code of ethics. While the concept has attracted substantial attention in the 1980s and thus far in the 1990s, the idea is hardly new in the public sector. The International City Managers Association adopted a code of ethics in 1942. The federal government issued ethical guidelines or codes in 1958, 1961, and 1978.

Since it came at the end of an era that ethicist Michael Josephson says listened to Wall Street rather than Main Street and valued success at the direct expense of ethics, the code issued by President Bush in 1989 takes on added historical significance. ${ }^{14}$ In April 1989, President Bush signed Executive Order 12674, "Principles of Ethical Conduct for Government Officers and Employees." The executive order directed the U.S. Office of Government Ethics to promulgate regulations establishing a single, comprehensive, and clear set of standards of conduct for the executive branch. The standards embody 14 principles of ethical service. ${ }^{15}$

Perhaps this code can be condensed to the following statement: obey and enforce the law, inform on those who do not, be fair, do not take money, and do not even look like you are doing something wrong. Or per-

14. In Bill Moyers, $A$ World of Ideas (New York: Doubleday, 1989), pp. 14-27.

15. These 14 points have been laid out in Stuart C. Gilman, "Presidential Ethics and the Ethics of the Presidency," this issue of The Annals of the American Academy of Political and Social Science. haps even more succinctly: obey the law. While more than 150 senior officials in the Reagan administration violated this code, it does not provide much guidance for the public administrator seeking to behave ethically in a situation where there is no applicable statute or where laws are unclear or in conflict.

Aclose look at another comprehensive analysis of public ethics might prove more instructive. By its own account, the American Society for Public Administration (ASPA) exists to advance the science, processes, and art of public administration. While there are no direct parallels, ASPA is to public administrators as the American Medical Association is to the medical profession. However, the differences between the two associations, their members, and their ethical codes could not be greater. The history and effectiveness of the Hippocratic oath are the envy of all other professions. The development of the ASPA code presents a somewhat different story.

ASPA's National Council did not approve a code of ethics until 8 April 1984, after ten years of discussion and debate between its members. The Code of Ethics as finally enacted begins with a prelude, which states in part:

ASPA members share with their neighbors all of the responsibilities and rights of citizens in a democratic society. However, the mission and goals of ASPA call every member to additional dedication. Conduct of ASPA members is not merely preventing wrong, in pursuing right through timely and energetic execution of responsibilities. To this end, we, the members of the Society, recognizing the critical role of conscience in choosing 
among courses of action and taking into account the moral ambiguities of life, commit ourselves to

- inspiring public trust through integrity, honesty, truthfulness, and fortitude;

- serving the public with respect and courtesy;

- achieving excellence and recruiting like-minded people to public service;

- being positive, creative, open, and compassionate;

- not becoming unduly rich from public service;

- not getting involved in conflicts of interest;

- keeping official secrets;

- using discretion in the public interest;

- keeping up to date on the profession and being competent, fair, impartial, efficient, and effective;

- being committed to affirmative action and equal opportunity;

- turning in those who commit waste, fraud, and abuse and supporting colleagues when they turn in others; and

- supporting and working to improve the federal and state constitutions. ${ }^{16}$

As with President Bush's Executive Order 12674, the ASPA code makes a number of moral statements that most Americans could agree with. Unfortunately, upon careful analysis, it is evident that neither code says much more than to obey the

16. American Society for Public Administration, National Council, "Code of Ethics and Implementation Guidelines," P.A. Times, 1 May 1993, supplement. law and, if the law is not clear, to do the right thing. Are codes thereby useless? We think not. As Pugh comments, a good code provides a modest level of behavioral guidance, cuts across and unifies a variety of occupations in the public service, and establishes a mechanism to ensure compliance with proper public professional behavior. ${ }^{17}$

But we agree with ethics scholar Kathryn Denhardt that codes of ethics are not enough. As Denhardt notes, codes provide broad clues for the public practitioner but fail to be sufficiently specific about how to practice the values they extol. What is the answer? Where does the public servant-indeed, the public-turn to find the path to a more efficient, effective, and moral government? Let us look at what the experts have to say.

\section{CREATING A MORE ETHICAL PUBLIC SERVICE}

We see two trends in the collective effort to create a more ethical public service: enforcement, and the reinforcement of values. Enforcement goes beyond the more theatrical efforts of federal prosecutors and congressional committees to bring highprofile violators of ethics or the law to justice. Enforcement is now a dayto-day reality for federal public servants as a result of the U.S. Inspector General Act of 1978, an act copied in a variety of forms by numerous states and localities across the country. The most common characterization associated with the Inspector General Act

17. Pugh, "Origins of Ethical Frameworks," pp. 9-32. 
is a desire to uncover and punish waste, fraud, and abuse.

Today there are inspectors general in sixty federal agencies, employing more than 15,000 workers. Inspectors general report to Congress twice a year and share their audit reports with their agency heads; however, they do not report to the agency head and the agency head cannot change anything in the report. Findings of the inspectors general are also forwarded to the U.S. attorney general for prosecution, as warranted. The reports of the inspectors general usually highlight the number of federal employees convicted as a result of their investigations and the amount of money collected.

How successful have the inspectors general been? As Paul Light notes, Congress, the public, and perhaps even the inspector general community itself were shocked to find that systemic corruption of virtually every form in virtually every division of the U.S. Department of Housing and Urban Development remained undetected by the agency inspector general until it was the subject of almost daily articles in the Wall Street Journal, the New York Times, the Washington Post, and the television networks' nightly news programs. As Light asks rhetorically, how could the inspector general not have known? ${ }^{18}$

In what we believe will become an enduring classic in the proactive analysis of public policymaking, Vice President Al Gore's National Perfor-

18. Paul C. Light, "Federal Ethics Control: The Role of Inspectors General," in Ethics and Public Administration, ed. Frederickson, p. 100 . mance Review report, Creating a Government That Works Better and Costs Less, submitted to President Clinton in September 1993, has much to say about the negative aspects of the inspector general system. The vice president's report notes that the Reagan-Bush focus on waste, fraud, and abuse shaped a mission for the inspectors general centered on uncovering mistakes and mismanagement, rather than on improving the efficiency and effectiveness of government programs. ${ }^{19}$

The Gore Commission report suggests that the current role of inspectors general is inhibiting innovation and risk taking among publicspirited civil servants and that the "heavy handed enforcement" of inspectors general is having a chilling impact on those public employees who are trying to make government more responsive to the public. The staff of the Gore Commission report observed that the inspectors general have created an environment where public employees feel compelled to follow every rule and fill out every form or risk losing their job. ${ }^{20}$

In his report, the vice president argues that the inspectors general need to broaden their role to focus on evaluating management control systems and helping managers do a better job of achieving what the public seeks from them, rather than highlighting their current level of inadequate performance. He recommends that the inspectors general focus on evaluating management control sys-

19. Al Gore, Creating a Government That Works Better and Costs Less (Washington, DC: Government Printing Office, 1993), pp. 31-32. 20. Ibid., p. 32. 
tems and on doing program evaluations. Finally, and interestingly, the vice president suggests that managers be surveyed to assess how good a job they think the inspector general is doing and that job performance measures be established and tracked for each inspector general.

What the vice president does not say is that the inspector general function should be abolished. We agree. There is no question that the inspector general powers are abused in some instances and that their impact often has an unintended negative effect on service delivery and customer service. Nevertheless, the internal audit function performed by inspectors general is common in the private sector and is often an effective check on waste, fraud, and abuse. Our point is simply that curtailing waste, fraud, and abuse does not necessarily promote ethical behavior, as the record of the upper levels of the federal government during the 1980 s documents. What then of the reinforcement of values as the road to a more ethical public service?

The literature of public administration speaks of values in terms of acting in the public interest. What is the public interest? John Dewey, who in 1927 thought we were losing our sense of community and a composite publicness different from selfishness, posited the values of loyalty, obedience, goodness, and compliance as the path to proper public behavior.

Noted public ethics scholar Reinhold Niebuhr, writing in the shadow of Nazi atrocities, wrote that a free society prospers when it is neither too pessimistic nor too optimistic concerning the nature of mankind. He divided us into children of light and children of darkness. Children of darkness are guided purely by selfinterest. Children of light, to which we should aspire to become, bring self-interest under the discipline of a higher law, presumably God's law.

Cold War theorist Walter Lippmann's definition is compelling and somewhat instructive: "The public interest may be presumed to be what men would choose if they saw clearly, thought rationally, acted disinterestedly and benevolently."21

Ethicist Michael Josephson provides a current version of the Lippmann doctrine: "Do more than you're required to do and less than you're allowed to do."22

In A Moral Sense, James Q. Wilson spends well over 200 thoughtprovoking pages trying to get at what we are trying to get at in less than a tenth of the space. Unfairly condensed, what Wilson argues is a dedication to four values-sympathy, fairness, self-control, and duty. Moreover, he argues, a moral sense is natural, with universal aspects. ${ }^{23}$

After all this discussion, we feel a great deal like Russell Baker must have felt when he wrote "Ethicizationism." As is his nature, Baker humorously observed something new showing up on television talk shows, the ethicist. He stated that no television show debating the rights and wrongs of public issues was complete without one. And what is an ethicist? Mr. Baker had a useful definition. He

21. Walter Lippmann, The Public Philosophy (New York: New American Library, 1955), p. 42.

22. In Moyers, World of Ideas, pp. 14-27.

23. James Q. Wilson, A Moral Sense (New York: Free Press, 1993). 
defined an ethicist as one who is devoted to the principle of "ethicism." The work he performs is referred to as "ethicizing"; it is also known as the "ethicization process." 24

While Baker was lighthearted, his piece was right on target. He went on to say that the ethicizing discipline grew out of an antique college philosophy course called ethics. Baker stated that, philosophy having withered away in America and the ethics course with it, we had been in philosophic drift for more than a century, which, Baker posited, had been particularly hard on politicians. As a result, politicians did not know how to react when faced with bribes. The importance of money in America had not declined, but the importance of philosophy had. Consequently, politicians drew a connection between money and goodness. ${ }^{25}$

Maybe Baker had something here. Is the route to a more ethical public service the development of more and better college courses on ethics? The serious ethical scholar Rohr seems to support the humorous Baker when he states that the academic literature has little to say on practical ethical questions such as conflict of interest and financial disclosure because academics find such questions "narrow, negative and boring." ${ }^{26}$ Ethics expert Bowman agrees, stating that "there is little ethical training for public service." ${ }^{27}$

24. Russell Baker, "Ethicizationism," New York Times, 27 Oct. 1990.

25. Ibid.

26. In Frederickson, ed., Ethics and Public Administration, p. xii.

27. Bowman, ed., Ethical Frontiers in Public Management, p. 1.
How could this training be most effectively accomplished? Ethicist Josephson argues for the use of role models. Carol Lewis agrees with the need for role models but also suggests that we need to reward positive behavior by means of recognition and to incorporate a developed ethical sense into civil service promotional examinations. So, finally, we have our answer. To create a more ethical public service, what we really need is more courses in ethics. Not so fast, says Michael Levin.

Levin maintains that the primary pedagogic methodology in ethics courses is the case study and that the approach is fundamentally flawed. $\mathrm{He}$ insists that it is training rather than reflection that encourages moral behavior, noting Aristotle's emphasis on the importance of promoting moral behavior among children as a means of fostering moral behavior in adults. ${ }^{28}$ Levin goes on to say that there is a role for philosophical reflection on the existence and nature of values but that its practical value is close to nothing. ${ }^{29}$ Tough words, but words worth considering. $\mathrm{He}$ adds that the distinction between right and wrong is not difficult to discern - the challenge lies in overcoming the inertia and timidity that prevent one from doing the right thing. Appropriate role models and reward systems, as parents soon learn, can enable children to meet this challenge. ${ }^{30}$

Levin further states that by focusing on ethical conflicts, ethics courses

28. Michael Levin, "Ethics Courses: Useless," New York Times, 25 Nov. 1989.

29. Ibid.

30. Ibid. 
simply provide an additional excuse to shrink from what most of us can clearly see as our duty in any public situation. In addition, he argues that ethics courses divert attention from the content of morality proper. To Levin, moral character does not require any particular stance on any particular public policy issue; it comes from truthfulness, diligence, and consideration. ${ }^{31}$

\section{IS THERE ANY POSITIVE GUIDANCE?}

To conclude, we return to Professor H. George Frederickson and then add some thoughts of our own. Professor Frederickson observes that definitions of corruption and ethics vary from profession to profession but that the most stringent standards apply to the administrative branch of government. Government's vast power and authority require high standards if individual freedom and liberty are to be maintained. Ironically, Frederickson notes that most of the corruption found on the administrative side of government comes from political appointees with no record of public service, not from civil servants. In fact, Frederickson maintains that the U.S. government is among the most ethical in the world, if not the most ethical. Ethical government is not without consequence: with honesty comes a sea of red tape and inaction. ${ }^{32}$

Frederickson also has a warning. He argues that the more we seek to

31. Ibid.

32. H. George Frederickson, "Ethics and Public Administration: Some Assertions," in Ethics and Public Administration, ed. Frederickson, pp. 247-58. make government more businesslike, the more corruption we will see. That is, the more we contract out and privatize, the higher the probability that corruption will result. Equally sobering, Frederickson is convinced that new procedures to cut down on corruption will move us closer and closer to policy gridlock. ${ }^{33}$

Given the difficulties of the questions addressed throughout this article, we would prefer to leave the reader to make his or her own judgments about what all the noted experts have to say about making government more ethical, and consider our job to be no more than bringing their opinions to the reader's attention. But as former practitioners and current educators of those who usually go on to careers in the public service, we will not let ourselves off that easily. Instead, we will posit a very strong and active statement on how to ensure that ethics are upheld on a personal or organizational level. ${ }^{34}$

It is not easy to analyze the ethical dimensions of public programs. However, while there may be few absolute, universal rules of morality, public servants must still judge the morality of the work they are given. Although some clear ethical principles exist and it is generally considered wrong to get involved in stealing, lying, and killing, governments are always violating the former and engaged in the latter. Public administrators must therefore make per-

33. Ibid.

34. The conclusion of this article draws heavily from Steven Cohen, The Effective Public Manager (San Francisco: Jossey-Bass, 1988). 
sonal value and moral judgments about the type of activities they are willing to perform. These judgments should not be made casually, and when taken seriously, they can require profoundly disturbing choices. Although the tenor of the times does not encourage serious consideration of ethical dilemmas, the best public managers develop an acute appreciation of the ethical dimensions of public decisions. Ethics in government does not typically involve consideration of new issues. Ethical issues are deeply rooted in the development of human civilization and are addressed by all of the holy books of Eastern and Western religions.

What is justice? What is appropriate charity and social responsibility? What is correct or moral behavior? What is legitimate authority? Public servants face these and other ethical issues all the time. They are recurring themes. In Ibsen's classic drama An Enemy of the People, a community notable faces the choice of either revealing his knowledge that a town's public baths are contaminated or keeping the information private to protect the town's economy. The analogy to modern environmental and public health policy is obvious, although we suspect many contemporary environmental managers would relish the prospect of such a clear-cut trade-off.

Typically, ethical issues are far from black and white. In the mid1980s, Oliver North lied to the Congress of the United States. He believed that his actions were justified by the higher cause of national defense. Franklin Roosevelt certainly deceived Congress with the same jus- tification during World War II. Of course, FDR was fighting a declared war and a widely acknowledged threat from Japan and Nazi Germany. North was fighting what he perceived to be the subtle threat of worldwide communism. He was also acting despite a specific prohibition by Congress. While we find it easy to agree with FDR's ethical choice and to disagree with North's, we do not believe that these are simple or clearcut ethical issues.

Assessing the ethical content of public servants' assignments requires that they project the likely effects of their actions and then analyze those effects according to their own concepts of morality. While it might sound frightening to have each individual apply a personal definition of morality to public actions, we have little alternative. We will simply have to hope that we share enough values and moral precepts to make sensible, consistent, and ethical public policy.

We believe that the greatest danger is not deliberately unethical government policy but inadvertently unethical public policy. In the crush of fast-moving events, ethical reflection is considered a luxury. Managers are not rewarded for taking the time to seriously consider the morality of their actions. Nevertheless, it is essential that managers weigh the ethics of the programs and policies they set in motion.

Each public servant lives both an official and an unofficial life. We all have friends in and out of our profession, public service. Sometimes we exchange gifts; sometimes we pick up each other's tabs at restaurants. If a 
person is in the government and there is any chance that a gift can be perceived as a bribe, it should not be accepted. If a public servant is in a restaurant with a vendor or a regulated party, he or she should pay his or her own way. If a public servant is making an investment, he or she should be certain that it has no relationship to his or her official responsibilities.

Those who work in the government should not expect to make a lot of money. People who need to make a lot of money should leave the government. The expertise and skills developed in the public sector will probably be marketable in the private sector. Once public servants have left the government, they must not recontact their old agency until ethics rules permit, usually one or two years after leaving. Corruption often starts small-with a free lunch or a bottle of Scotch at Christmas. If public administrators do not draw an absolute line, they may soon be rationalizing larger and less subtle payoffs.

By refusing all gifts, public administrators avoid the need to analyze which ones to accept. While we realize this may force public officials to be less sociable than they might prefer, this is simply the price of public service.

Albert Hirschman, in Exit, Voice, and Loyalty, identifies three choices that public administrators have if they disagree with an assignment. They can leave the organization (exit), they can go public with their opposition (voice), or they can mute their opposition in order to retain their influence within the organization (loyalty). ${ }^{35}$ Essentially the same choices are open if their disagreement is based on ethics. While it is true that operating in the real world involves compromise and accommodation, every individual must draw the line somewhere.

The trials in Nuremburg of Nazis charged as war criminals after World War II demonstrated that individual public servants are accountable to universal ethical standards. If public servants believe an assignment is wrong, they should try to reverse the decision. If they are unsuccessful, they must weigh the three options Hirschman identifies.

There is no prescription we can offer for weighing these ethical choices. Public administrators will not last long in any organization if they see every decision as an ethical choice. Nor will they sleep well if they violate their own code of morality.

In our view, Carol Lewis gives the best specific advice for the ethical behavior of public administrators in her 21 rules of thumb, which we have reduced to five principles:

1. Obey and implement the law.

2. Serve the public interest.

3. Avoid doing harm.

4. Take individual responsibility for the process and its consequences.

5. Treat incompetence as an abuse of office. ${ }^{36}$

35. Hirschman, Exit, Voice, and Loyalty (Cambridge, MA: Harvard University Press, 1970).

36. Lewis, Ethics Challenge, pp. 164-78. 